\title{
Studies on protozoa in ancient remains - A Review
}

\author{
Liesbeth Frías ${ }^{1}$, Daniela Leles ${ }^{2}$, Adauto Araújo ${ }^{1 /+}$ \\ 'Escola Nacional de Saúde Pública-Fiocruz, Rio de Janeiro, RJ, Brasil 2Departamento de Microbiologia e Parasitologia, \\ Instituto Biomédico, Universidade Federal Fluminense, Rio de Janeiro, RJ, Brasil
}

Paleoparasitological research has made important contributions to the understanding of parasite evolution and ecology. Although parasitic protozoa exhibit a worldwide distribution, recovering these organisms from an archaeological context is still exceptional and relies on the availability and distribution of evidence, the ecology of infectious diseases and adequate detection techniques. Here, we present a review of the findings related to protozoa in ancient remains, with an emphasis on their geographical distribution in the past and the methodologies used for their retrieval. The development of more sensitive detection methods has increased the number of identified parasitic species, promising interesting insights from research in the future.

Key words: paleoparasitology - mummies - coprolites - infectious diseases - protozoa - paleoepidemiology

Since the beginning of the last century, paleoparasitology has been focused on understanding the origin and evolution of infectious diseases, relying on archaeological and paleontological material to do so. A wide diversity of intestinal parasites has been retrieved from ancient remains, primarily from helminths (Gonçalves et al. 2003). However, although protozoa exhibit a global distribution, they are not recovered easily from archaeological contexts. This scarcity might be related to difficulties in detecting these organisms using traditional optical microscopy and to the sensitivity of parasitic structures, which are less resistant to taphonomic processes, leading to a low estimation of protozoa in the archaeological record.

This literature review aims to identify and summarise the geographic distribution of protozoa in the archaeological record, with an emphasis on protozoa associated with humans, including both intestinal and tissue parasites and the methodologies used to study them in ancient remains. An electronic database search was performed targeting studies on protozoa in the fields of paleoparasitology, archaeology and paleopathology and authors showing previous research efforts on this subject. The search comprised all publications found on this topic in PubMed and ScienceDirect and their bibliographies were screened as well. The data extracted from the literature included parasite species, archaeological sites and dates, the methods applied and the results of the studies. There were no exclusions related to publication dates or languages.

Methodological approaches to the identification of protozoa

Although macroscopic examinations of lesions are generally limited to making observations of body preservation and the presence of specific landmarks, this

Financial support: CNPq, FAPERJ

+ Corresponding author: adauto@ensp.fiocruz.br

Received 1 October 2012

Accepted 23 November 2012 technique is the most direct way of approaching disease in archaeological remains. For example, Chagas disease was diagnosed based on an altered large intestinal tract in a pre-Columbian mummy (Reinhard et al. 2003) and later confirmed via molecular biological methods (Dittmar et al. 2003). However, this finding was exceptional, as the majority of infectious diseases will not be detected using such methodology. Consulting historical documents provides an indirect method for approximating protozoan infections. By reviewing medical documents, autopsy reports and original death certificates recorded by court physicians, Gino Fornaciari et al. (2010a, b) reconstructed the medical history of one of the most influential families of the Italian Renaissance, the Medici (Nerlich et al. 2012).

In a similar manner, the origin of leishmaniasis in the Americas was discussed based on ethno-historical documents and anthropomorphic representations on Mochica ceramics (huacos) showing lesions similar to those found in mucous leishmaniasis (Altamirano-Enciso et al. 2003).

Microscopy has been the traditional method for parasite identification in paleoparasitological analyses and the first protozoa found in fossilised faeces (coprolites) were described using this technique (Pizzi \& Schenone 1954, Witenberg 1961, Fouant et al. 1982). Unfortunately, most of these early findings were not accompanied by photographs or images, preventing comparisons with later studies.

Immunofluorescence and enzyme-linked immunosorbent assays (ELISA) have been the most commonly employed techniques for antigen recognition in ancient remains. Biochemical techniques were initially used in this field in 1989, when Faulkner et al. (1989) applied indirect immunofluorescence to identify Giardia cysts from human coprolites dated to 2,177 \pm 145 years before present (BP). Since that time, various intestinal parasites have been successfully identified via these techniques in coprolites around the world (for a review, see Gonçalves et al. 2003).

With the development of methods for ancient DNA recovery, tracing parasitic diseases became possible. Analyses of ancient DNA in the field of paleoparasi- 
tology were first performed in experimental animal mummies and demonstrated that molecular techniques could recover parasitic DNA from archaeological material (Bastos et al. 1996). In paleoparasitology, molecular biological methods have been used primarily for species confirmation, resulting in the identification of falciparum malaria, visceral leishmaniasis (VL) and Chagas disease. However, there are limitations to these techniques. The need to retrieve small DNA fragments from parasitic structures that are difficult to preserve and are usually associated with material of uncertain archaeological dates makes further analyses difficult.

Several parasites of animal species have been recovered from coprolites of human origin, suggesting false parasitism in some cases and zoonosis in others. Most of these studies have been performed on helminths. However, many of the infections considered to be zoonoses, such as cryptosporidiosis and giardiasis, can only be confirmed through molecular characterisation of genotypes and subgenotypes. No enteric protozoa have been identified by these methods to date. Nevertheless, beyond the application of these techniques for diagnostic purposes, they would expand the ability to study protozoan infections in the past.

\section{A brief history of studies on protozoa in ancient remains}

The analysis of protozoa in the archaeological record (Fig. 1) relies on the distribution and availability of ancient remains, the ecology of infectious diseases and the use of adequate detection techniques. Studies conducted in amber specimens have provided an idea of how old the association with protozoans is (Table I). The discovery of a trypanosomatid (of the genus Paleoleishmania) within a female sandfly in Cretaceous Burmese amber indicates that vector-borne parasites already existed by the Early Cretaceous (Poinar \& Poinar 2004). The description of a trypanosomatid from faecal droplets adjacent to Triatoma dominicana provides the first fossil evidence of a triatomine-trypanosomatid vector association, dating to the midTertiary era (Poinar 2005a). The presence of Plasmodium dominicana in a Tertiary Dominican Republic amber specimen establishes a minimum age for the genus Plasmodium and places avian malaria in the Americas by the mid-Tertiary, supporting earlier theories that some species responsible for primate malaria could have evolved in the Americas (Poinar 2005b). Indirect evidence based on the frequency of erosive lesions found in tyrannosaurids suggests infection by a Trichomonas gallinae-like protozoan and represents the first report of an avian-transmissible disease in non-avian theropod dinosaurs (Wolff et al. 2009). Cysts similar to those of the extant genus Entamoe$b a$ have been preserved in coprolites from the Early Cretaceous, enabling the description of two new genera and species, Entamoebites antiquus (Poinar \& Boucot 2006) and Endamoebites proterus (Poinar 2009). Unsporulated coccidian oocysts (Archeococcidia antiquus sp. nov. and Archeococcidia nothrotheriopsae sp. nov.) have also been described in coprolites from a Shasta ground sloth (Nothrotheriops shastensis) (Schmidt et al. 1992).

In addition, Eimeria oocysts from various animal species have been retrieved from archaeological contexts. The first such report refers to oocysts in deer coprolites dated to $9000 \mathrm{BP}$ from northeastern Brazil, for which a new species (Eimeria lobatoi) was suggested (Ferreira et al. 1992) and oocysts of Eimeria macusaniensis and Eimeria ivitaensis have been detected in mummified camelids from Peru (Leguía et al. 1995, Leguía 1999). More recently, E. macusaniensis was recovered from various archaeological sites in Santa Cruz, Argentina (Fugassa \& Barberena 2006, Fugassa \& Guichón 2006, Fugassa 2007, Fugassa et al. 2007, Beltrame et al. 2010), where the host specificity of this species enabled more reliable identification of camelids in archaeological deposits. Furthermore, by comparing the dimensions of oocysts from these archaeological sites, a temporal trend was established indicating a size reduction over time (Fugassa et al. 2008). This discovery offers insight into hostparasite coevolution and paleoenvironmental changes.

A large number of publications have addressed the study of mummified human remains, which have shown preservation varying from excellent to very poor (Lyn-

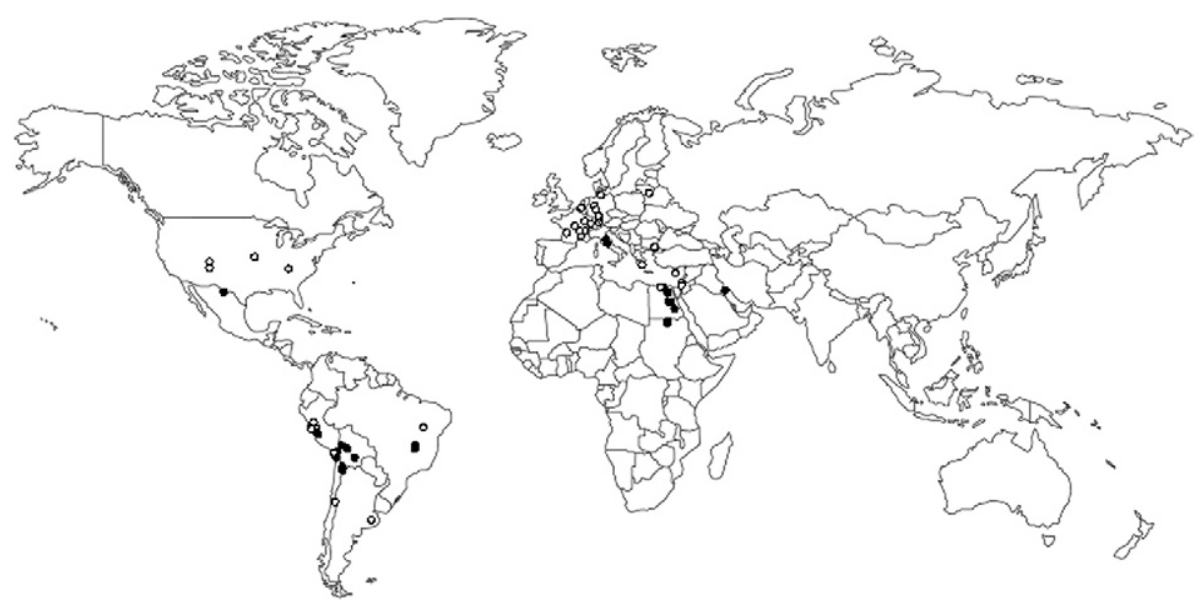

Fig. 1: paleodistribution of enteric protozoa (white spots) and blood protozoa (black spots) in humans. 


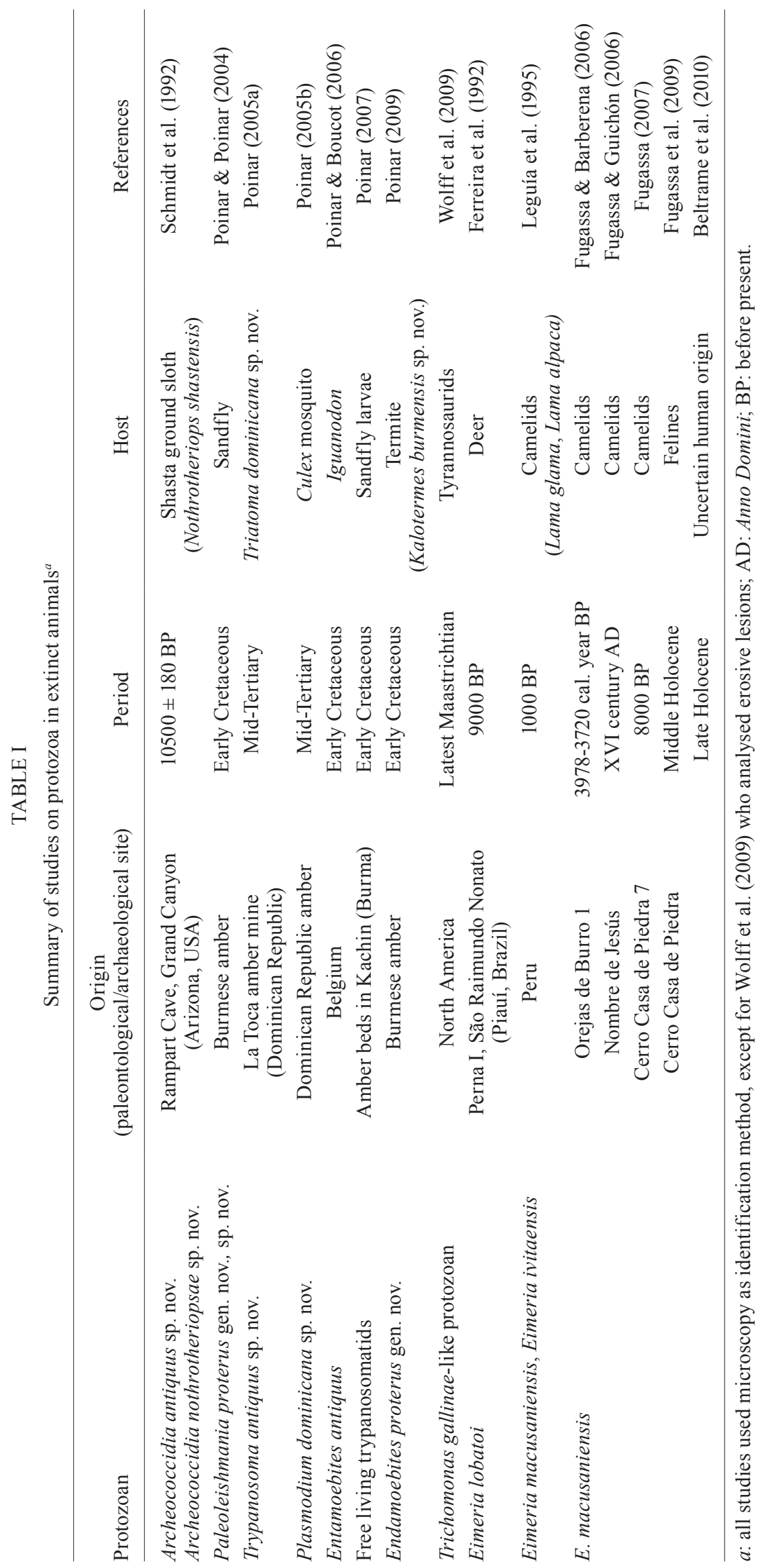


nerup 2007). Soft tissue preservation depends on rapid dehydration overtaking postmortem decay and can be brought about either by natural conditions (a hot or very cold dry climate) or via artificial means (mortuary practices preventing degradation). Hence, the dry and salty climate of the Saharan and Atacama Deserts, the cold winds and permanent ice of the Andean Cordillera and the aridity of the Argentinean Pampas and Brazilian Savannah (Cerrado and Caatinga) present ideal conditions for tissue preservation. Similarly, bodies within sealed tombs are generally well preserved, facilitating the identification of diseases that do not necessarily leave traces in bone (Cockburn et al. 1998, Aufderheide 2003).

Enteric protozoa are expected to be found worldwide, as gastrointestinal infections represent one of the oldest and most common associations of infectious disease with humanity. In addition, these organisms do not require specific vectors, as they are generally transmitted by contaminated food and water. Blood protozoa, on the other hand, depend strongly on the distribution of their vectors and, consequently, on various environmental factors.

Forty-eight publications addressing protozoa found in human remains (Table II) were retrieved from the electronic databases, ranging from the year 1954-2012. The number of publications from the present century was equal to the number published from the 1950s-1990s. The first descriptions of enteric protozoa in archaeological remains were secondary to findings of larger parasites (Pizzi \& Schenone 1954, Witenberg 1961, Faulkner et al. 1989). Subsequently and with the growing availability of commercial kits that enable parasite retrieval from coprolites, the number of studies on protozoa increased. For example, Giardia duodenalis, Cryptosporidium parvum and Entamoeba spp have been successfully identified in samples from both the New and the Old World, dating to between $5300 \mathrm{BP}$ and the XIX century (Gonçalves et al. 2004, Le Bailly \& Bouchet 2006).

Unlike enteric protozoa, blood protozoa have historically attracted the interest of more researchers, primarily because of their epidemiological importance in public health. The use of molecular techniques has enabled confirmation of Chagas disease in Andean mummies dating back to 9000 BP (Aufderheide et al. 2004) and falciparum malaria in ancient Egyptian mummies dating to 5200 BP (Miller et al. 1994, Cerutti et al. 1999, Rabino Massa et al. 2000, Nerlich et al. 2008).

\section{TABLE II}

Publications on protozoa in ancient human remains

\begin{tabular}{lccc}
\hline & \multicolumn{2}{c}{$\begin{array}{c}\text { Publications } \\
\text { (n) }\end{array}$} & \\
\cline { 2 - 3 } & New World & Old World & Total \\
\hline Enteric protozoa & 10 & 5 & 15 \\
Blood protozoa & 16 & 17 & 33 \\
\hline Total & 26 & 22 & 48 \\
\hline
\end{tabular}

Blood protozoa - Chagas disease in the pre-Columbian Americas - Trypanosoma cruzi, the causative agent of American trypanosomiasis, or Chagas disease, is transmitted through the faecal droppings of infected vectors from the subfamily Triatominae. T. cruzi is geographically restricted to the Americas and occurs primarily in Latin America, where it is endemic (Moncayo \& Silveira 2009). Its paleodistribution was also constrained to the New World, comprising the Andean area, a small region in the Brazilian savannah and part of the Chihuahuan Desert in North America (Fig. 2, Table III).

Descriptions of cases of T. cruzi infections in the past are relatively abundant in the literature. The identification of amastigote nests in cardiac fibres from a Peruvian mummy (Fornaciari et al. 1992) and visceral lesions in Chilean mummies (Rothhammer et al. 1985) confirms the occurrence of both the infection and disease in pre-Columbian times. Humans were infected early in their history and were likely infected in various ways, depending on how they interacted with their environment. The existence of Chagas disease in pre-Columbian populations predates sedentism and domestication by several thousand years, suggesting other means of initial contagion. Some authors propose that accidental infection of humans occurred due to contact with natural $T$. cruzi foci (Guhl et al. 2000) and that human dwellings and domestication would have subsequently facilitated its establishment in domestic settings (Aufderheide et al. 2004). Various alternatives have been put forth regarding how this would have happened. The ingestion of raw infected meat was suggested as a potential route of infection by Neghme (1982), but archaeological evidence was not provided until almost 20 years later, when Reinhard et al. (2003) reported finding unburned bones and hair from woodrats in coprolites from an area where a case of Chagas disease was described and later molecularly confirmed (Dittmar et al. 2003). The occupation of caves and rock shelters, before dwellings were intro-

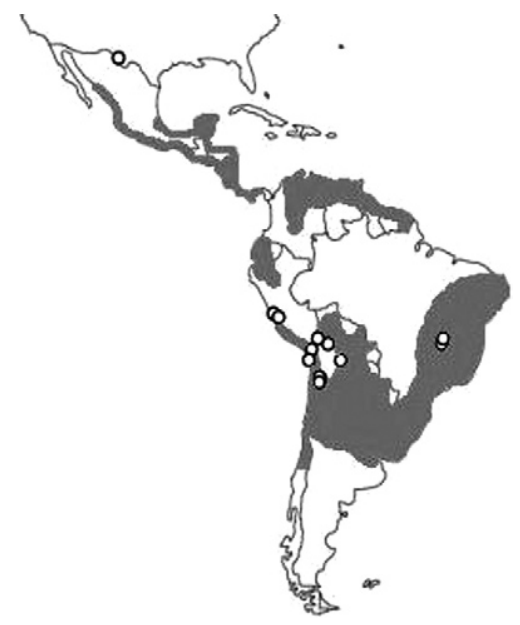

Fig. 2: paleodistribution of Trypanosoma cruzi studies in humans (white spots). Grey area approximately represents the current geographic extent of Chagas disease in Central and South America (adapted from Silveira 1999). 


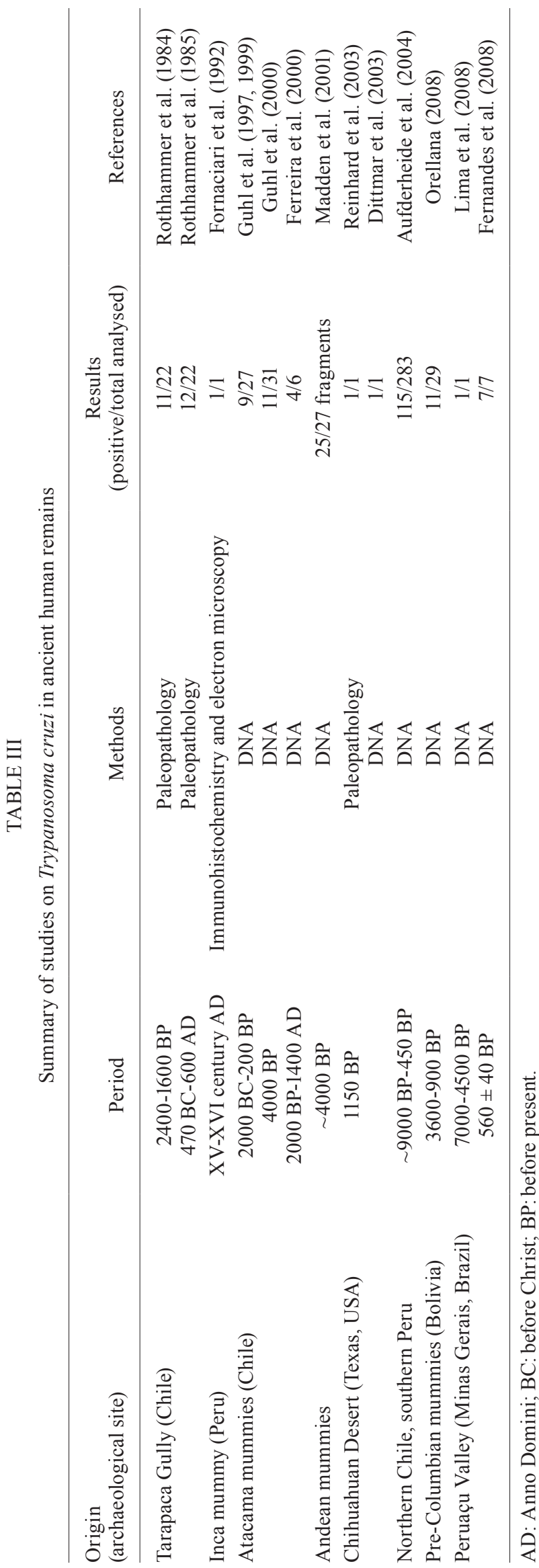

duced, would also have increased the risk of infection by triatomine species adapted to live in rocks (Araújo et al. 1998, Ferreira et al. 2000). The T. cruzi infections described from the archaeological record were reviewed by Ferreira et al. (2011) regarding the origin and spread of Chagas disease.

Malaria - Human malaria is one of the most common infectious diseases in the world. It is transmitted by infected female mosquitoes of the genus Anopheles, which inject malaria parasites while feeding. There are five species known to infect humans, among which Plasmodium falciparum accounts for the death of more than one million people every year (Snow et al. 2005). This infection exhibits a widespread distribution in tropical and subtropical areas, with the highest transmission currently found in the Amazonas, Sub-Saharan Africa, India and parts of Oceania (CDC 2012).

Studies in ancient remains have provided evidence of endemic malaria in Egypt and Italy (Fig. 3, Table IV), where proximity to river valleys would have resulted in a high risk of acquiring malaria, as river flooding produces perfect breeding sites for mosquitoes. Despite the lack of treatments for malaria and references to disease symptoms in ancient Egyptian texts, some texts do note the presence of mosquitoes and the use of nets to avoid them (Strouhal 1992, Nunn 2001, Herodotus 2008). Symptoms including an enlarged spleen accompanied by fever are mentioned in the Papyrus Ebers (Ebbell 1937), but no clear description of malaria is given. In the vicinity of the Tiber, the discovery of a large Roman children's cemetery, dating to 430 BC (Soren et al. 1995), suggests that an epidemic outbreak of malaria occurred, as falciparum malaria is known to cause a high rate of premature deliveries in non-immune pregnant women.

It is worth noting that malaria antigen detection tests are not as sensitive as microscopy. Although some researchers have been able to recover P. falciparum histidine-rich protein 2 using the ParaSight ${ }^{\mathrm{TM}}$-F test (Miller et al. 1994, Cerutti et al. 1999), some of these results were not reproducible in further investigations (Taylor et al. 1997). Subsequently, studies on living patients showed cross-reaction of the monoclonal IgG antibody used in this test with the rheumatoid factor in blood, resulting in false positive tests for malaria (Iqbal et al. 2000, Moody 2002).

The occurrence of malaria in the Americas has been subject to great debate among historians (for a review, see Bruce-Chwatt 1965). Those defending its pre-Columbian presence argue that there is linguistic evidence indicating the symptoms of the disease (Guerra 1964, cited in Bruce-Chwatt 1965, p. 378) and botanical evidence of the therapeutic use of cinchona bark (Jaramillo-Arango 1950, cited in Bruce-Chwatt 1965, p. 379). Nevertheless, the historical evidence for and against a pre-Columbian existence of malaria is controversial; there are no known references to the disease nor to the cinchona plant in the available written records from the Incas, Mayas or Aztecs. Moreover, for one or two generations after the first arrival of the Spaniards, there were no reports of diseases that might be considered to be ma- 
laria, not even in localities that were later known to be associated with a high malaria burden (Ashburn 1947). Regarding the use of bark, it is believed that the native Indians of Peru would have transmitted their knowledge of its use to Jesuit missionaries after the Conquest, in 1527 (Bruce-Chwatt 1965). Recent phylogenetic analyses and Approximate Bayesian Computation methods suggest independent introductions of two clusters of $P$. falciparum from African origins in South America, favouring multiple introductions from Africa during the transatlantic slave trade (Yalcindag et al. 2012).

Leishmaniasis - Leishmaniasis is a parasitic disease caused by protozoa of the genus Leishmania. It is endemic in southern Europe, North Africa, the Middle East, Central and South America and India (Piscopo \& Azzopardi 2007). Infections involving this parasite are regarded as cutaneous (CL), mucocutaneous (ML) or VL, which present different geographic distributions and clinical manifestations. More than $90 \%$ of all VL cases occur in India, Bangladesh, Nepal, Sudan, Ethiopia and Brazil, $90 \%$ of all CL is reported in Afghanistan, Algeria, Iran, Saudi Arabia, Syria, Brazil, Colombia, Peru and Bolivia and more than $90 \%$ of all cases of ML occur in Bolivia, Brazil, Ethiopia and Peru (WHO 2012).

The antiquity of leishmaniasis in the New World has been inferred from the existence of huacos with facial mutilations, references from chroniclers of the Conquest and Colonial Period and the persistence of some quechua words that make allusions to the disease (Altamirano-Enciso 2000). The evidence of Leishmania in the archaeological record is scarce. The presence of these parasites in the high-altitude Atacama Desert, where the disease is not normally found, suggests a pattern of mobility from endemic areas (Costa et al. 2009, Marsteller et al. 2011) dating to as early as $1000 \mathrm{BP}$ (Fig. 4, Table V). An analogous situation was proposed for leishmaniasis in Egypt, where expeditions to Nubia (modern Sudan), currently a highly endemic country for VL (Zink et al. 2006), would explain the high incidence of Leishmania DNA in the Middle Kingdom, as opposed to its absence in earlier or later periods. Leishmania infantum was recently identified in Eleanor of Toledo (1522-1562), a Spanish noble woman and wife of Cosimo I de'Medici and in mummies from the Brazilian Colonial Period, 1530-1815 (ongoing research), which is in accordance with studies confirming the recent importation of this parasite into the New World from southwest Europe (Kuhls et al. 2011).

Enteric protozoa - Paleoparasitological evidence of protozoans is scarce. Because their cysts and oocysts are fragile microstructures compared to helminth eggs, the identification of these organisms from archaeological remains via optical microscopy has been infrequent. The application of ELISA greatly improved the detection of protozoa infections in coprolites and latrine soils in the Americas and Europe (Table VI) and Gonçalves et al. (2002) concluded that the sensitivity of this technique was greater than that offered by microscopy for diagnosing G. duodenalis. Cryptosporidium spp and G. duodenalis have been identified based on immunofluorescence analysis in archaeological remains in Peru, dating to as early as 4300 BP (Ortega \& Bonavia 2003), while in Europe, Le Bailly et al. (2008) identified G. duodenalis in samples from medieval times using immunofluorescence and ELISA. More recently, the detection of $G$. duodenalis and Entamoeba histolytica in archaeological samples from the Middle East has confirmed written evidence of the occurrence of infective diarrhoea in the Crusader period (Mitchell et al. 2008).

The case of Toxoplasma gondii - T. gondii is a widespread zoonotic protozoan that infects most species of mammals, birds, fish, amphibians and reptiles. To detect this parasite in ancient remains, one of the following scenarios must occur. In the first scenario, the infective stage of the parasite (oocysts) must be found in the co-

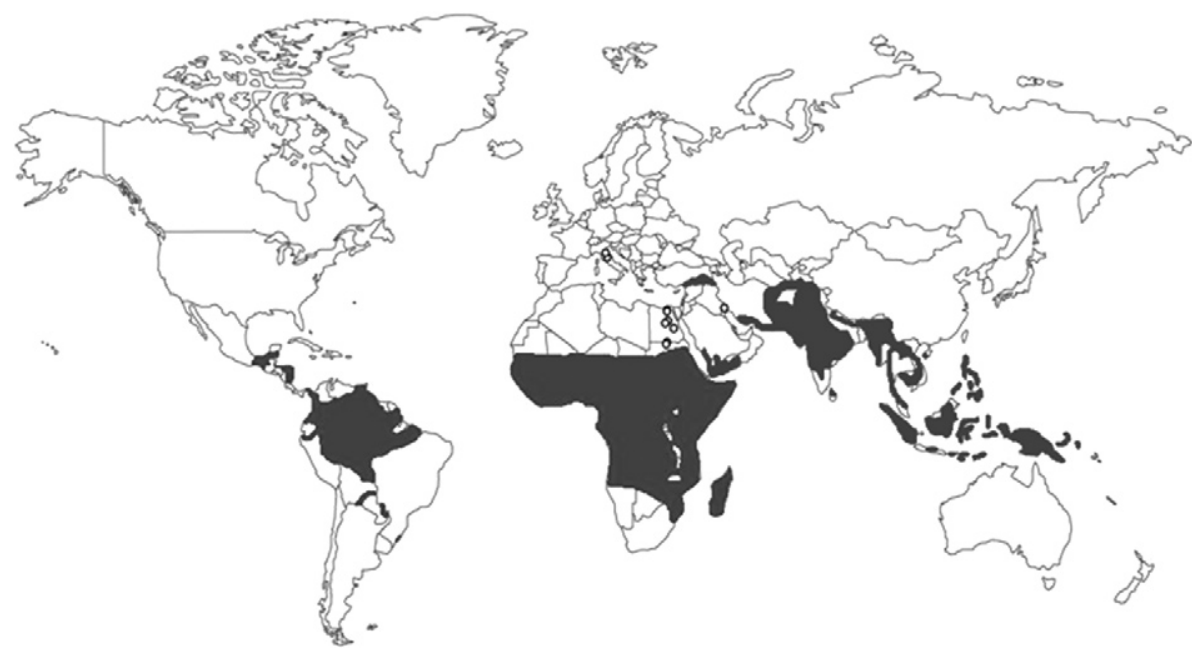

Fig. 3: paleodistribution of Plasmodium falciparum studies in humans (white spots). Grey area approximately represents the current geographic distribution of the disease (CDC 2012). 


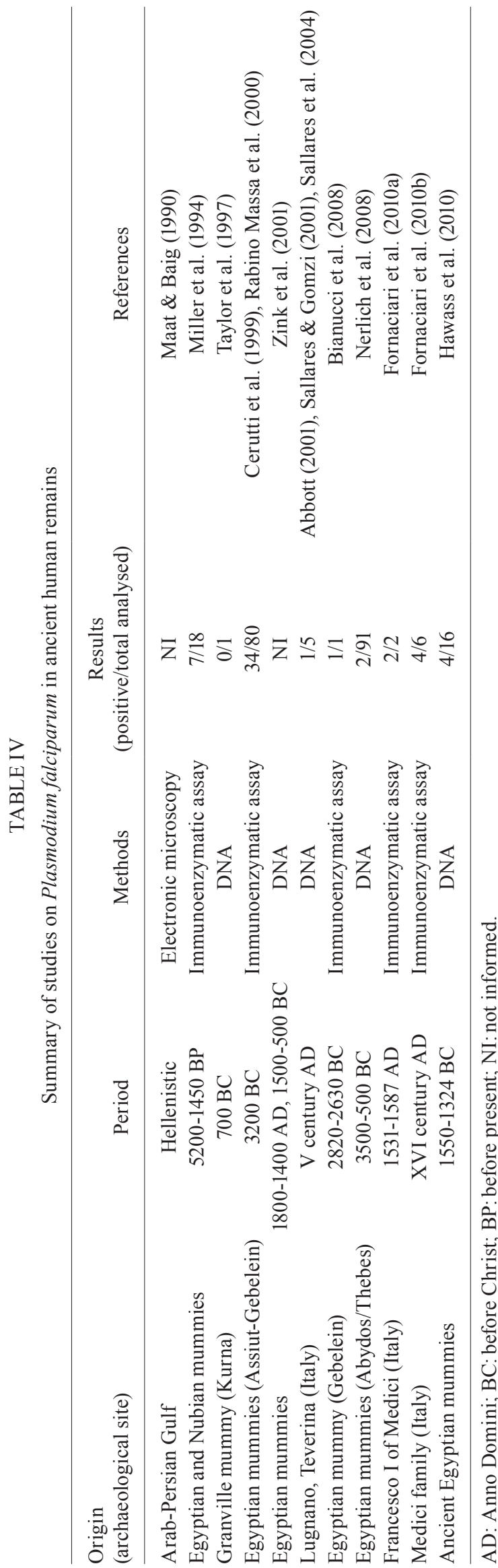

prolites of felids, as they are the only definitive host for $T$. gondii. In the second scenario, encysted forms of the parasite (bradyzoites) have to be retrieved from various tissues of the body, either from intermediary hosts (animals, including humans) or infected cats. The complex life cycle of $T$. gondii limits the potential for its identification in coprolites because, although its oocysts are shed in the faeces of adult cats in some cases, oocyst excretion usually occurs only in young felids, which are less immunocompetent (Dubey et al. 1977, Dubey 1995). Toxoplasma has not yet been detected in ancient remains, although successful recovery of its DNA has been accomplished from desiccated mouse tissue (Terra et al. 2004). Although methodological difficulties must be considered, the worldwide dispersion of the infection today suggests the possibility of finding the parasite through systematic examinations of mummies and archaeological remains.

The ecology of infectious diseases in humans entails more than the risk of acquiring an infection. It also involves the likelihood of exposure, the conditions of establishment and favourable circumstances that lead to successful transmission. While adapting to harsh environments, human populations have become part of various parasitic life cycles. For malaria, proximity to marshy areas favours the incidence of disease, as seen in the Nile Delta (Rabino Massa et al. 2000) and the fringes of the Tiber valley (Sallares \& Gomzi 2001). Additionally, members of the Medici family are known to have hunted in areas of Tuscany endemic for malaria (Fornaciari et al. 2010a, b). Chagas disease is thought to have originated from a human intrusion into the T. cruzi syl-

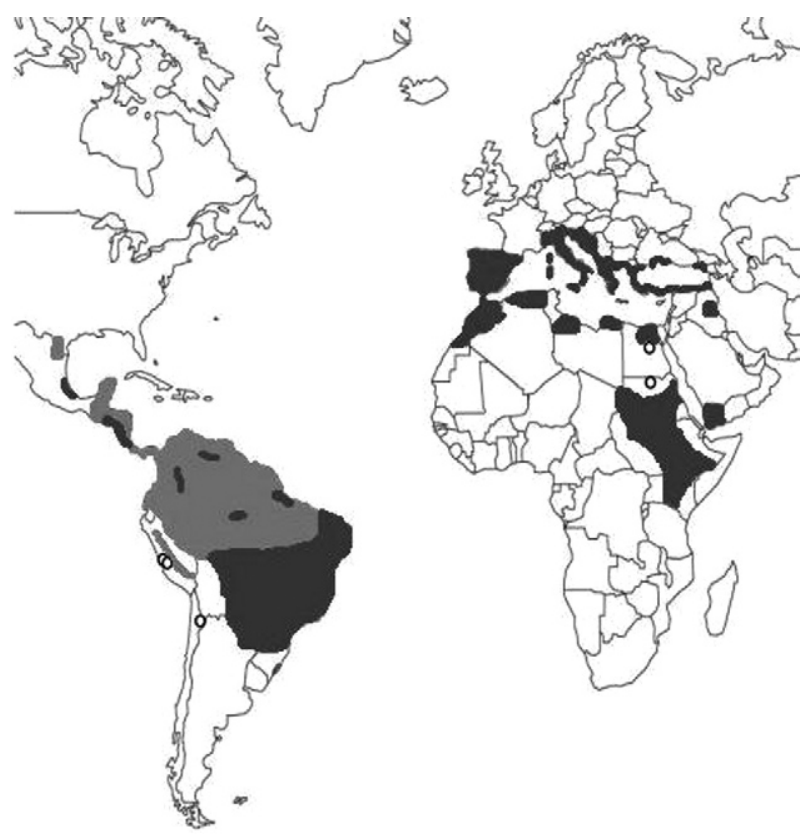

Fig. 4: paleodistribution of Leishmania spp studies in humans (white spots). Grey areas approximately represent the current distribution of visceral leishmaniasis (dark grey) and cutaneous-mucocutaneous (light grey) in the New World. 


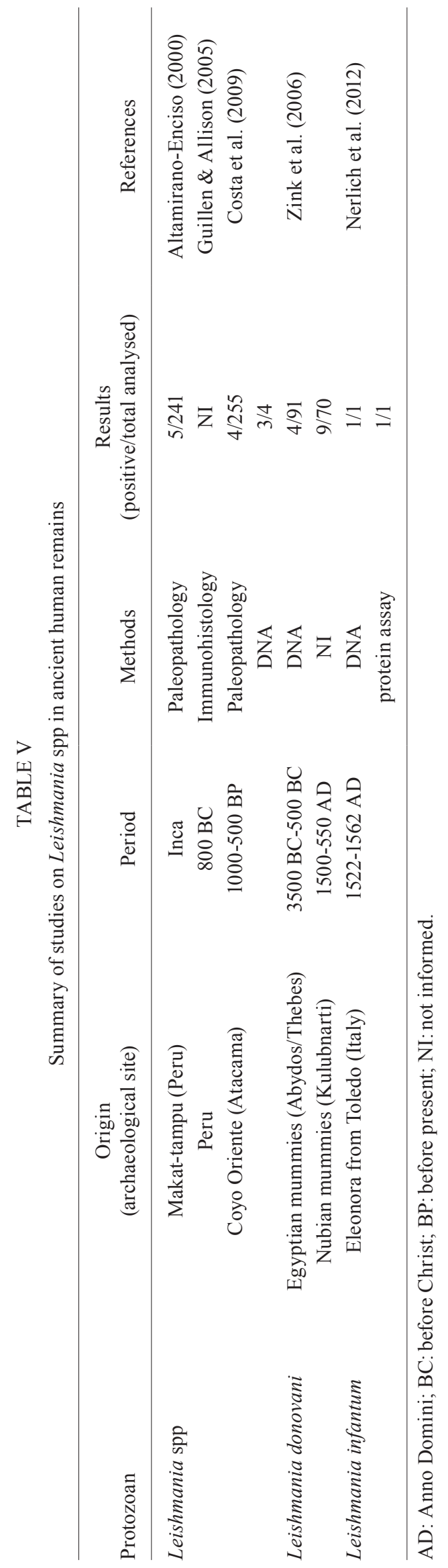

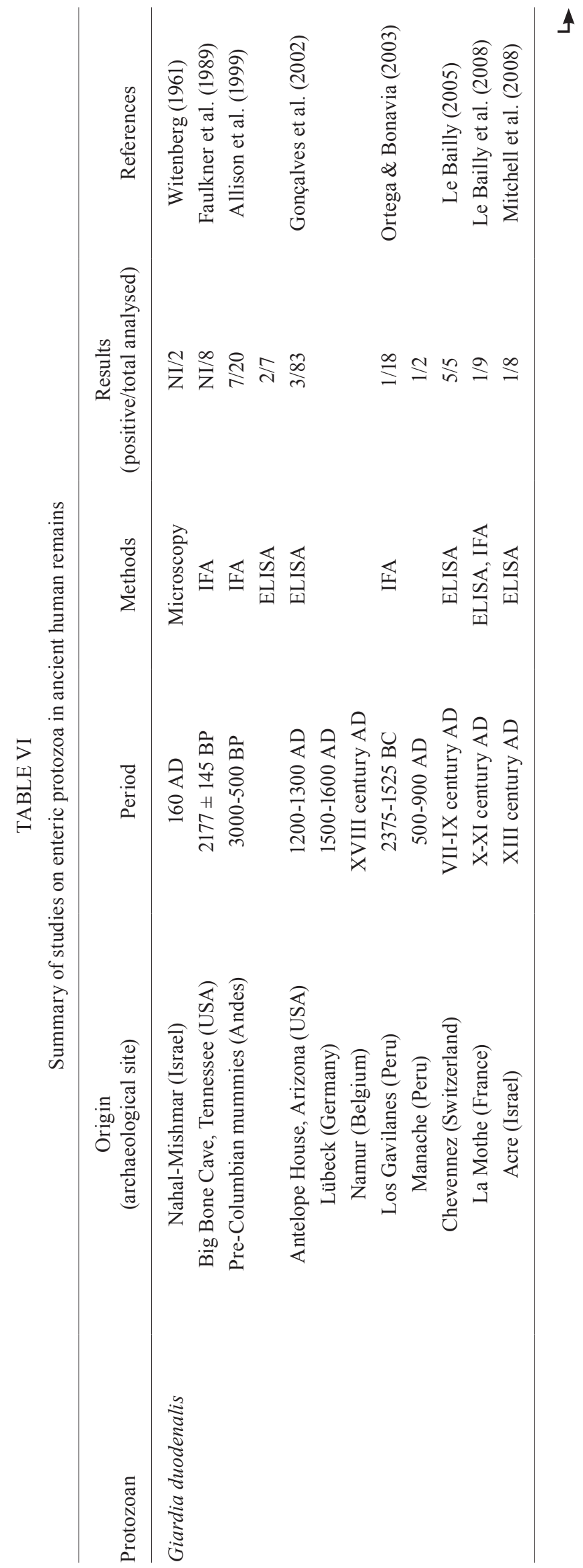




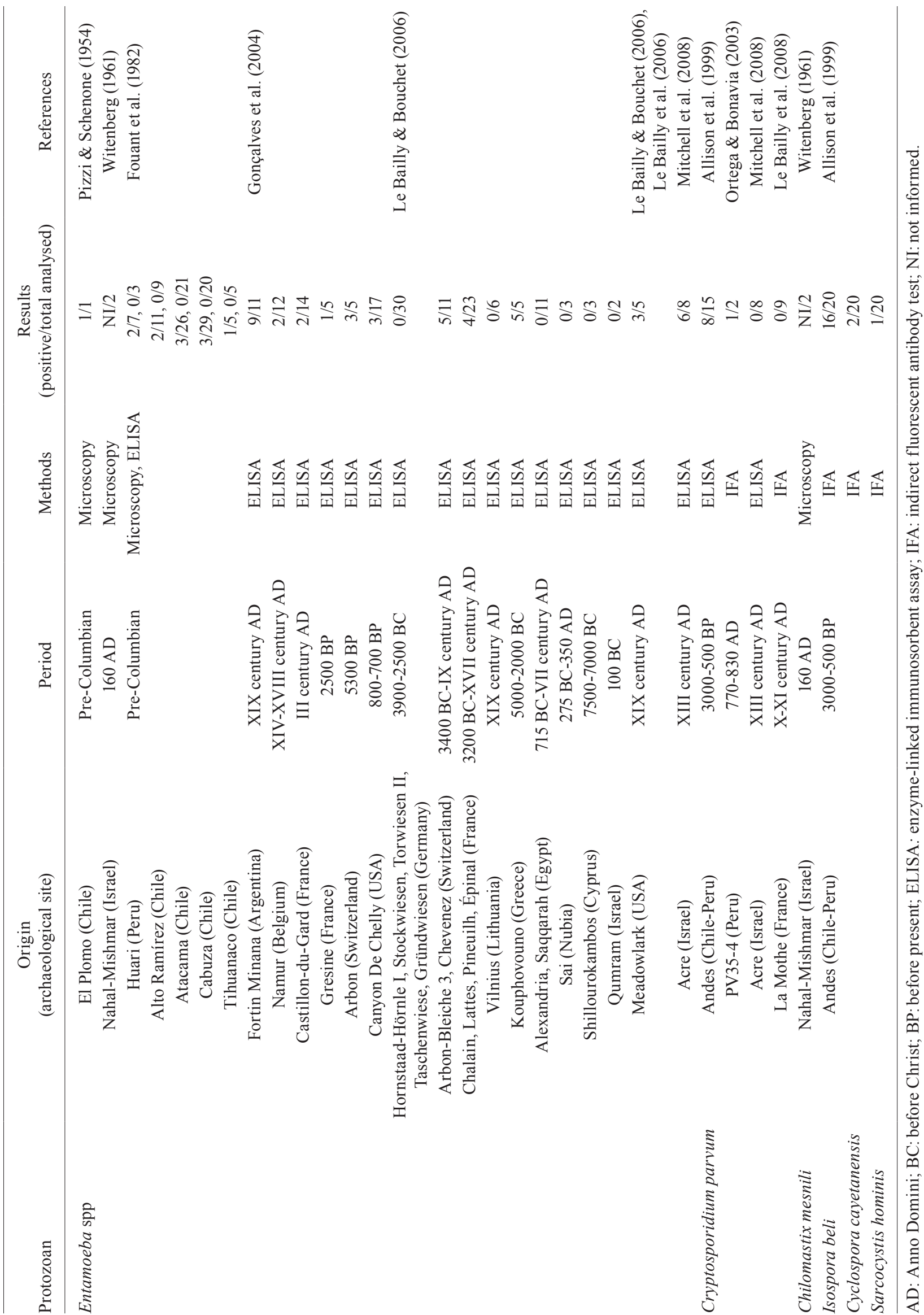


vatic cycle, gradually transitioning into a domestic cycle (Aufderheide et al. 2004, Araújo et al. 2009, Ferreira et al. 2011) and leishmaniasis would have increased in the New World due to travel to endemic zones or migration from such areas (Costa et al. 2009).

The probability of detecting parasites is sometimes enhanced by the methodology applied. Studies on enteric protozoa have increased with the availability of commercial kits that facilitate the processing of a large number of samples simultaneously. Molecular biological techniques offer a more sensitive methods to retrieve information from archaeological contexts and even though limitations associated with ancient DNA must be considered (such as sample preservation, age and contamination), examination of enteric protozoa using these means would offer an interesting perspective on the zoonotic potential of Giardia spp and Cryptosporidium spp in the archaeological record, an emphasis that has not yet been explored in the literature.

\section{REFERENCES}

Abbott A 2001. Earliest malaria DNA found in Roman baby graveyard. Nature 412: 847 .

Allison MJ, Bergman T, Gerszten E 1999. Further studies on parasites in antiquity. Am J Clin Pathol 112: 605-609.

Altamirano-Enciso AJ 2000. Comprometiendo la estructura osteofacial de las poblaciones humanas del antiguo Perú por la leishmaniasis tegumentaria de forma mucosa, PhD Thesis, ENSP/ Fiocruz, Rio de Janeiro, 213 pp.

Altamirano-Enciso AJ, Marzochi MCA, Moreira JS, Schubach AO, Marzochi KBF 2003. Sobre a origem e dispersão das leishmanioses cutânea e mucosa com base em fontes históricas pré e póscolombianas. Hist Cienc Saude Manguinhos 10: 853-882.

Araújo A, Jansen AM, Reinhard K, Ferreira LF 2009. Paleoparasitology of Chagas disease - A Review. Mem Inst Oswaldo Cruz 104 (Suppl. I): 9-16.

Araújo A, Reinhard K, Bastos OM, Costa LC, Pirmez C, Iñiguez AM, Vicente AC, Morel CM, Ferreira LF 1998. Paleoparasitology: perspectives with new techniques. Rev Inst Med Trop Sao Paulo 40: 371-376.

Ashburn PM 1947. The ranks of death. A medical history of the Conquest of America, Frank D. Ashburn, New York, 298 pp.

Aufderheide A 2003. The scientific study of mummies, Cambridge University Press, Cambridge, $496 \mathrm{pp}$.

Aufderheide AC, Salo W, Madden M, Streitz J, Buikstra J, Guhl F, Arriaza B, Renier C, Wittmers LE Jr, Fornaciari G, Allison M 2004. A 9,000-year record of Chagas disease. Proc Natl Acad Sci USA 101: 2034-2039.

Bastos OM, Araújo A, Ferreira LF, Santoro A, Wincker P, Morel CM 1996. Experimental paleoparasitology: identification of Trypanosoma cruzi DNA in desiccated mouse tissue. Paleopathol Newsl 94: 5-8.

Beltrame MO, Fugassa MH, Sardella NH 2010. First paleoparasitological results from late Holocene in Patagonian coprolites. J Parasitol 96: 648-651.

Bianucci R, Mattutino G, Lallo R, Charlier PH, Jouin-Spriet H, Peluso A, Higham T, Torre C, Rabino Massa E 2008. Immunological evidence of Plasmodium falciparum infection in a child mummy from the Early Dynastic Period. J Archaeol Sci 35: 1880-1885.

Bruce-Chwatt LJ 1965. Paleogenesis and paleo-epidemiology of primate malaria. Bull World Health Organ 32: 363-387.
CDC - Centers for Diseases Control and Prevention 2012. Malaria. [updated 2012 April 17, cited 2012 June 12]. Available from: cdc. gov/malaria/.

Cerutti N, Marin A, Massa ER, Savoia D 1999. Immunological investigation of malaria and new perspectives in paleopathological studies. Boll Soc Ital Biol Sper 75: 17-20.

Cockburn A, Cockburn E, Reyman TA 1998. Mummies, disease and ancient cultures, Cambridge University Press, Cambridge, 428 pp.

Costa MA, Matheson C, Iachetta L, Llagostera A, Appenzeller O 2009. Ancient leishmaniasis in a highland desert of northern Chile. PLOS ONE 4: e6983.

Dittmar K, Jansen AM, Araújo A, Reinhard K 2003. Molecular diagnosis of prehistoric T. cruzi in the Texas-Coahuila border region. Paleopathol Newsl (Suppl.): 4.

Dubey JP 1995. Duration of immunity to shedding of Toxoplasma gondii oocysts by cats. J Parasitol 81: 410-415.

Dubey JP, Hoover EA, Walls KW 1977. Effect of age and sex on the acquisition of immunity to toxoplasmosis in cats. $J$ Eukaryot Microbiol 24: 184-186.

Ebbell 1937. The Papyrus Ebers, the greatest Egyptian medical document, Levin \& Munksgaard, Copenhagen, 135 pp.

Faulkner C, Patton S, Johnson S 1989. Prehistoric parasitism in Tennessee: evidence from the analysis of desiccated fecal material collected from Big Bone Cave, Van Buren County, Tennessee. J Parasitol 75: 461-463.

Fernandes A, Iñiguez AM, Lima VS, Mendonça de Souza SMF, Ferreira LF, Vicente ACP, Jansen AM 2008. Pre-Columbian Chagas disease in Brazil: Trypanosoma cruzi I in the archaeological remains of a human in Peruaçu Valley, Minas Gerais, Brazil. Mem Inst Oswaldo Cruz 103: 514-516.

Ferreira LF, Araújo A, Confalonieri U, Chame M, Ribeiro B 1992. Eimeria oocysts in deer coprolites dated from 9,000 years BP. Mem Inst Oswaldo Cruz 87 (Suppl. I): 105-106.

Ferreira LF, Britto C, Cardoso MA, Fernandes O, Reinhard K, Araújo A 2000. Paleoparasitology of Chagas disease revealed by infected tissues from Chilean mummies. Acta Trop 75: 79-84.

Ferreira LF, Jansen AM, Araújo A 2011. Chagas disease in prehistory. An Acad Bras Cienc 83: 1041-1044.

Fornaciari G, Castagna M, Viacava P, Tognetti A, Bevilacqua G, Segura E 1992. Chagas disease in a Peruvian Inca mummy. Lancet 339: 128-129.

Fornaciari G, Giuffra V, Ferroglio E, Gino S, Bianucci R 2010a. Malaria was the killer of Francesco I de Medici (1531-1587). Am J Med 123: 568-569.

Fornaciari G, Giuffra V, Ferroglio E, Gino S, Bianucci R 2010b. Plasmodium falciparum immunodetection in bone remains of members of the Renaissance Medici family (Florence, Italy, sixteenth century). Trans R Soc Trop Med Hyg 104: 583-587.

Fouant MM, Allison M, Gerszten E, Focacci G 1982. Parásitos intestinales entre los indígenas precolombinos. Chungara 9: 285-295.

Fugassa MH 2007. Camélidos, parásitos y ocupaciones humanas: registros paleoparasitológicos en Cerro Casa de Piedra 7 (Parque Nacional Perito Moreno, Santa Cruz, Argentina). Intersecciones antropol 8: 265-269.

Fugassa MH, Araújo A, Sardella N, Denegri GM 2007. New paleoparasitological finding in caves from Patagonia, Argentina. Paleopathol Newsl 137: 17-21.

Fugassa MH, Barberena R 2006. Cuevas y zoonosis antiguas: paleoparasitología del sitio Orejas de Burro 1 (Santa Cruz, Argentina). Magallania (Punta Arenas) 34: 57-62. 
Fugassa MH, Beltrame MO, Bayer MS, Sardella NH 2009. Zoonotic parasites associated with felines from the Patagonian Holocene. Mem Inst Oswaldo Cruz 104: 1177-1180.

Fugassa MH, Guichón RA 2006. Nuevos aportes a la paleoparasitología del sitio arqueológico "Nombre de Jesús" (S. XVI), Cabo Vírgenes, Argentina. Rev Arg Antrop Biol 8: 73-83.

Fugassa MH, Sardella NH, Taglioretti V, Reinhard KJ, Araújo A 2008. Eimeriid oocysts from archaeological samples in Patagonia, Argentina. J Parasitol 94: 1418-1420.

Gonçalves MLC, Araújo A, Duarte R, Pereira da Silva J, Reinhard K, Bouchet F, Ferreira LF 2002. Detection of Giardia duodenalis antigen in coprolites using a commercially available enzyme-linked immunosorbent assay. Trans R Soc Trop Med Hyg 96: 640-643.

Gonçalves MLC, Araújo A, Ferreira LF 2003. Human intestinal parasites in the past: new findings and a review. Mem Inst Oswaldo Cruz 98 (Suppl. I): 103-118.

Gonçalves MLC, Silva V, Andrade C, Rocha G, Le Bailly M, Bouchet F, Ferreira LF, Araújo A 2004. Amoebiasis distribution in the past: first steps in using an immunoassay technique. Trans $R$ Soc Trop Med Hyg 98: 88-91.

Guhl F, Jaramillo C, Vallejo GA, A-Arroyo FC, Aufderheide A 2000. Chagas disease and human migration. Mem Inst Oswaldo Cruz 95: 553-555

Guhl F, Jaramillo C, Vallejo GA, Yockteng R, A-Arroyo FC, Fornaciari G, Arriaza B, Aufderheide AC 1999. Isolation of T. cruzi DNA in 4.000-year-old mummified human tissue from northern Chile. Am J Phys Anthropol 108: 401-407.

Guhl F, Jaramillo C, Yockteng R, Vallejo GA, A-Arroyo FC 1997. T. cruzi DNA in human mummies. Lancet 349: 1370.

Guillen S, Allison M 2005. An early case of South American leishmaniasis in Peru, 1st PAMinSA, Rio de Janeiro, p. 61.

Hawass Z, Gad YZ, Ismail S, Khairat R, Fathalla D, Hasan N, Ahmed A, Elleithy H, Ball M, Gaballah F, Wasef S, Fateen M, Amer H, Gostner P, Selim A, Zink A, Pusch CM 2010. Ancestry and Pathology in King Tuthankhamun's Family. JAMA 303: 638-647.

Herodotus 2008. The histories, Oxford University Press, Oxford, p. $840 \mathrm{pp}$.

Iqbal J, Sher A, Rab A 2000. Plasmodium falciparum histidine-rich protein 2-based immunocapture diagnostic assay for malaria: cross-reactivity with rheumatoid factor. J Clin Microbiol 38: $1184-1186$

Kuhls K, Alam MZ, Cupolillo E, Ferreira GE, Mauricio IL, Oddone R, Feliciangeli MD, Wirth T, Miles MA, Schönian G 2011. Comparative microsatellite typing of new world Leishmania infantum reveals low heterogeneity among populations and its recent world origin. PLoS Negl Trop Dis 5: e1155.

Le Bailly M 2005. Evolution de la relation hote/parasite dans les systèmes lacustres nord alpins au Néolithique (3900-2900 BC), et nouvelles données dans la détection des paléoantigènes de Protozoa, PhD Thesis, Université de Rims Champagne Ardenne, Reims, $291 \mathrm{pp}$.

Le Bailly M, Bouchet F 2006. Paléoparasitologie et immunologie: l'exemple d'Entamoeba histolytica. Archéosciences 30: 129-135.

Le Bailly M, Gonçalves MLC, Harter-Lailheugue S, Prodéo F, Araujo A, Bouchet F 2008. New finding of Giardia intestinalis (Eukaryote, Metamonad) in Old World archaeological site using immunofluorescence and enzyme-linked immunosorbent assays. Mem Inst Oswaldo Cruz 103: 298-300.

Le Bailly M, Gonçalves MLC, Lefèvre C, Roper DC, Pye JW, Araujo A, Bouchet F 2006. Parasitism in Kansas in the 1800s. A glimpse to the past through the analysis of grave sediments from Meadowlark cemetery. Mem Inst Oswaldo Cruz 101 (Suppl. II): 53-56.

Leguía GP 1999. Enfermedades parasitarias de camélidos sudamericanos, De Mar, Lima, 190 pp.

Leguía GP, Casas AE, Wheeler J 1995. Parasitismo en camélidos prehistóricos. Parasitol dia 19: 435.

Lima VS, Iñiguez AM, Otsuki K, Fernando Ferreira L, Araújo A, Vicente AC, Jansen AM 2008. Chagas disease in ancient huntergatherer populations, Brazil. Emerg Infect Dis 14: 1001-1002.

Lynnerup N 2007. Mummies. Yearb Phys Anthropol 50: 162-190.

Maat G, Baig M 1990. Scanning electron microscopy of fossilized sickle-cells. Int J Anthropol 5: 2716.

Madden M, Salo WL, Streitz J, Aufderheide A, Fornaciari G, Jaramillo C, Vallejo GA, Yockteng R, Arriaza B, A-Arroyo FC, Guhl F 2001. Hybridization screening of very short PCR products for paleoepidemiological studies of Chagas disease. Biotechniques 30: $102-104$.

Marsteller SJ, Torres-Rouff C, Knudson KJ 2011. Pre-Columbian Andean sickness ideology and the social experience of leishmaniasis: a contextualized analysis of bioarchaeological and paleopathological data from San Pedro de Atacama, Chile. Int J Paleopathol 1: 24-34.

Miller RL, Ikram S, Armelagos GJ, Walker R, Harer WB, Shiff CJ, Baggett D, Carrigan M, Maret SM 1994. Diagnosis of Plasmodium falciparum infections in mummies using the rapid manual ParaSight-F Test. Trans R Soc Trop Med Hyg 88: 31-32.

Mitchell PD, Stern E, Tepper Y 2008. Dysentery in the crusader kingdom of Jerusalem: an ELISA analysis of two medieval latrines in the city of Acre (Israel). J Archaeol Sci 35: 1849-1853.

Moncayo A, Silveira AC 2009. Current epidemiological trends for Chagas disease in Latin America and future challenges in epidemiology, surveillance and health policy. Mem Inst Oswaldo Cruz 104 (Suppl. I): 17-30.

Moody A 2002. Rapid diagnostic tests for malaria parasites. Clin Microbiol Rev 15: 66-78.

Neghme A 1982. La tripanosomiasis en América. Creces 3: 23-28.

Nerlich AG, Bianucci R, Trisciuoglio A, Schönian G, Ball M, Giuffra V, Bachmeier B, Pusch CM, Ferroglio E, Fornaciari G 2012. Leishmaniasis during Italian Renaissance, 1522-1562. Emerg Infect Dis 18: 184-186.

Nerlich AG, Schraut B, Dittrich S, Jelinek TH, Zink A 2008. Plasmodium falciparum in Ancient Egypt. Emerg Infect Dis 14: 1317-1318.

Nunn JF 2001. Oxford Encyclopedia of Ancient Egypt, American University in Cairo Press, Cairo, 398 pp.

Orellana NCH 2008. Paleogenética de populações pré-colombianas da Bolivia: análise do mtDNA humano e infecção por Trypanosoma cruzi e vírus linfotrópico das células T humanas (HTLV), MsD Thesis, Fiocruz, Rio de Janeiro, 85 pp.

Ortega YR, Bonavia D 2003. Cryptosporidium, Giardia and Cyclospora in ancient Peruvians. J Parasitol 83: 635-636.

Piscopo TV, Azzopardi CM 2007. Leishmaniasis. Postgrad Med J 83: 649-657.

Pizzi T, Schenone H 1954. Hallazgo de huevos de Trichuris trichiura en el contenido intestinal de un cuerpo arqueológico arcaico Inca. Bol Chil Parasitol 9: 73-75.

Poinar Jr G 2005a. Triatoma dominicana sp. n. (Hemiptera: Reduviidae: Triatominae) and Trypanosoma antiquus sp. n. (Stercoraria: Trypanosomatidae), the first fossil evidence of a triatomine-trypanosomatid vector association. Vector Borne Zoonotic Dis 5: 72-81. 
Poinar Jr G 2005b. Plasmodium dominicana n. sp. (Plasmodiidae: Haemospororida) from Tertiary Dominican amber. Syst Parasitol 61 : 47-52.

Poinar Jr G 2007. Early Cretaceous trypanosomatids associated with fossil sand fly larvae in Burmese amber. Mem Inst Oswaldo Cruz 102: 635-637.

Poinar Jr G 2009. Description of an early Cretaceous termite (Isoptera: Kalotermitidae) and its associated intestinal protozoa, with comments on their co-evolution. Parasit Vectors 2: 12.

Poinar Jr G, Boucot AJ 2006. Evidence of intestinal parasites of dinosaurs. Parasitology 133: 245-249.

Poinar Jr G, Poinar R 2004. Paleoleishmania proterus n. gen., n. sp., (Trypanosomatidae: Kinetoplastida) from Cretaceous Burmese amber. Protist 155: 305-310.

Rabino Massa E, Cerutti N, Savoia D 2000. Malaria in ancient Egypt: paleoimmunological investigations in predynastic mummified remains. Chungara 32: 7-9.

Reinhard K, Fink TM, Skiles J 2003. A case of megacolon in Rio Grande Valley as a possible case of Chagas disease. Mem Inst Oswaldo Cruz 98 (Suppl. I): 165-172.

Rothhammer F, Standen V, Núñez L, Allison MJ, Arriaza B 1984. Origen y desarrollo de la tripanosomiasis en el área Centro-Sur Andina. Chungara 12: 155-160.

Rothhammer F, Standen V, Núñez L, Allison MJ, Arriaza B 1985. Chagas disease in Pre-Columbian South America. Am J Phys Anthropol 68: 495-498.

Sallares R, Bouwman A, Anderung C 2004. The spread of malaria to southern Europe in antiquity: new approaches to old problems. Med Hist 48: 311-328.

Sallares R, Gomzi S 2001. Biomolecular archaeology of malaria. Anc Biomol 3: 195-213.

Schmidt GD, Duszynski DW, Martin PS 1992. Parasites of the extinct Shasta ground sloth, Nothrotheriops shastensis, in Rampart Cave, Arizona. J Parasitol 78: 811-816.

Silveira AC 1999. Current situation with the control of vector borne Chagas disease transmission in the Americas. In Atlas of Chagas disease vector in the Americas, 1st ed., Fiocruz, Rio de Janeiro, p. 1161-1181.

Snow RW, Guerra CA, Noor AM, Myint HY, Hay SI 2005. The global distribution of clinical episodes of Plasmodium falciparum malaria. Nature 434: 214-217.

Soren D, Fenton T, Birkby W 1995. The late Roman infant cemetery near Lugano in Teverina, Italy: some implications. J Paleopathol 7: $13-42$.

Strouhal E 1992. Life of the ancient Egyptians, American University in Cairo Press, Cairo, $280 \mathrm{pp}$.

Taylor GM, Rutland P, Molleson T 1997. A sensitive polymerase chain reaction method for the detection of Plasmodium species DNA in ancient human remains. Anc Biomol 1: 193-203.

Terra MABL, Bello AR, Bastos OM, Amendoeira MRR, Coelho JMCO, Ferreira LF, Araújo A 2004. Detection of Toxoplasma gondii DNA by polymerase chain reaction in experimentally desiccated tissues. Mem Inst Oswaldo Cruz 99: 185-188.

WHO - World Health Organization 2012. Leishmaniasis. [updated 2012; cited 2012 June 12]. Available from: who.int/topics/leishmaniasis/en/.

Witenberg G 1961. Human parasites in archaeological findings. Bull Israel Ex Soc 25: 86.

Wolff EDS, Salisbury SW, Horner JR, Varricchio DJ 2009. Common avian infection plagued the tyrant dinosaurs. PLOS ONE 4: e7288.

Yalcindag E, Elguero E, Arnathau C, Durand P, Akiana J, Anderson TJ, Aubouy A, Balloux F, Besnard P, Bogreau H, Carnevale P, D'Alessandro U, Fontenille D, Gamboa D, Jombart T, Le Mire J, Leroy E, Maestre A, Mayxay M, Ménard D, Musset L, Newton PN, Nkoghé D, Noya O, Ollomo B, Rogier C, Veron V, Wide A, Zakeri S, Carme B, Legrand E, Chevillon C, Ayala FJ, Renaud F, Prugnolle F 2012. Multiple independent introductions of Plasmodium falciparum in South America. Proc Natl Acad Sci USA 109: 511-516.

Zink A, Haas CJ, Herberth K, Nerlich AG 2001. PCR amplification of Plasmodium DNA in ancient human remains. Anc Biomol 3: 293.

Zink AR, Spigelman M, Schraut B, Greenblatt CL, Nerlich AG, Donoghue HD 2006. Leishmaniasis in ancient Egypt and Upper Nubia. Emerg Infect Dis 12: 1616-1617. 